[단보, Short communication]

Korean J. Malacol. 29(4): 385-387 2013

\title{
A new record of Turbo (Callopoma) excellens (Turbinidae: Sorbeoconcha: Gastropoda) from Korea
}

\author{
Jun-Sang Lee and Yong-Seok Lee \\ Institute of Environmental Research, Kangwon National University, Chunchon 200-701 \\ ${ }^{1}$ Department of Life Science and Biotechnology, College of Natural Sciences, Soonchunhyang University
}

\section{ABSTRACT}

The specimens of Turbo (Callopoma) excellens were collected from Jejudo Island by scuba diving, and diagnostic characters were analysed. This is the first occurrence report the Turbo (Callopoma) excellens Sowerby III, 1914 from Korea.

Key words: Turbo (Callopoma) excellens, first report, Jejudo Island, Korea

\section{INTRODUCTION}

The Turbinid shells are medium to large in size, up to more than $200 \mathrm{~mm}$ in diameter, turbinate to conical form and characterised by the partially or fully calcified operculum and by a series of novel radular features. The shells mainly live in shallow water, often in reef association habitats, in warm temperate and tropical seas, and feed on plant material, especially algae.

The Turbinidae have been treated in nine subfamilies, Moelleriinae, Prisogasterinae, Colloniinae, Liotiinae, Angariinae, Turbininae, Gabieloninae, Tricholiinae and Phasianellinae (Beesley et al., 1998). There are 85 species in six subfamily from Japan (Higo et al., 1999), four species in one genus from Russia (Kantor \& Sysoev, 2006), and 16 species in seven genera from China (Qi, 2004) have been reported respectively. Korean molluscan fauna have

Received: December 10, 2013; Revised: December 18, 2013; Accepted: December 20, 2013

Corresponding author: Jun-Sang Lee

Tel: +82 (33) 250-7409 e-mail: sljun@kangwon.ac.kr $1225-3480 / 24507$

This is an Open Access article distributed under the terms of the Creative Commons Attribution Non-Commercial License with permits unrestricted non-commercial use, distribution, and reproducibility in any medium, provided the original work is properly cited. been established with 12 species belonging to 10 genera (Choe and Park, 1997). Recently, 16 species belonging to 11 genera have been reported (Lee \& Min, 2002; Min et al., 2004).

By adding one unrecorded species reporting in this study, the family Turbinidae contains 17 species belonging to 11 genera in Korea. The specimens used in this study were deposited in Min Molluscan Research Institute in Seoul, Korea.

\section{SYSTEMATIC ACCOUNT}

Class Gastropoda Cuvier, 1791 복족강

Superorder Caenogastropoda Cox, 1959 신생복족상목

Order Sorbeoconcha Ponder and Lindberg, 1997 흡강목

Family Turbinidae Rafinesque, 1815 소라과

Genus Turbo Linnaeous, 1758 소라속

Subgenus Callopoma Gray, 1850 예쁜눈알고둥아속 (신칭)

Turbo (Callopoma) excellens G.B. Sowerby III, 1914. 예쁜눈알고둥 (신칭) (Fig.1).

Turbo excellens G.B. Sowerby III, 1914, pp. 33-39, pl. 2. Callopomella excellens: Okada et al., 1967, p. 38, no. 110. Turbo (Callopomella) excellens: Habe \& Okutani, 1975, p. 54, p. 243; Higo \& Goto, 1993, p. 47.

Turbo (Callopoma) excellens: Higo et al., 1999, p. 47; Okutani et al., 2000, p. 97, pl. 48, fig. 31; Min et al., 2004, p. 93, fig. 84 . 
A new record of Turbo (Callopoma) excellens (Turbinidae: Sorbeoconcha: Gastropoda) from Korea

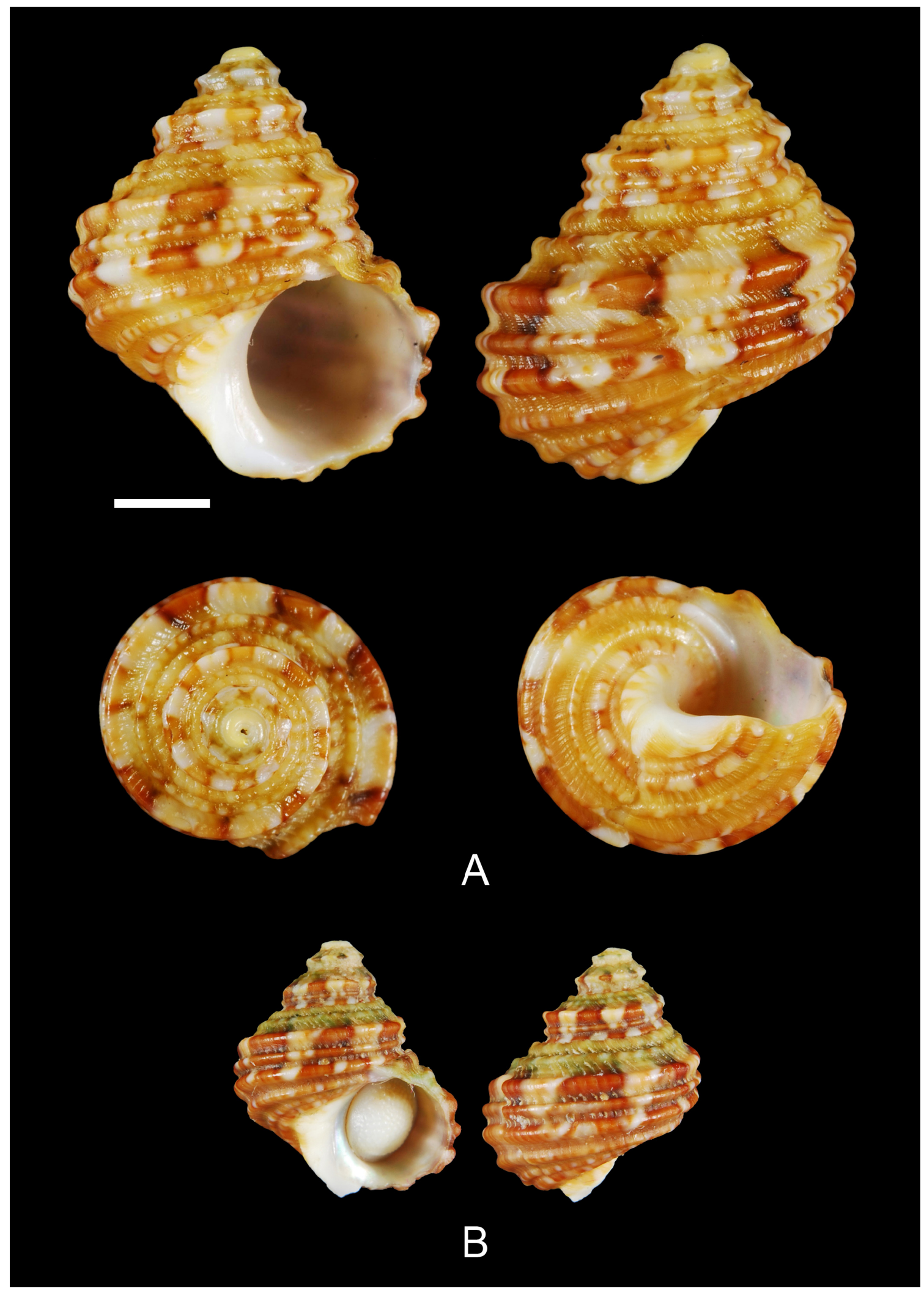

Fig. 1. Turbo (Callopoma) excellens. A, Adult form; B, Juvenile form. Scale Bar=5 mm. 
Type locality. off Nagashima, eastern Kii penisula (Japan).

Materials examined. 2 individuals, 16 Aug 2003, Jeju-do, Seogwipo-si, Beophwan-dong, Munseom; 11 July 2008, Jeju-do, Seogwipo-si, Hwasun beach.

Measurement. Shell height $25 \mathrm{~mm}$; Shell width 20 $\mathrm{mm}$.

Description. Shell moderately medium, solid and thick, turbinate in shape with length greater than width. Spire well developed, moderately pointed, whorls convex and with angular shoulders. Outer sculpture with rounded, equal spiral cords and many fine oblique threads, most developed on the interstics of cords. Body whorl biangulate, with stronger three spiral cords at shoulder and periphery. Base of whorl with three wide apace stronger spiral cords. Aperture rounded ovate, about less than half the total length of shell, with a thick, serrate outer lip. Columella smooth, not flaring anteriorly, umbilicus closed. Operculum nearly circular in outline, deep furrows in central and abaxial part. Outside of shell reddish brown or yellowish brown coloured. Aperture glossy white, becoming silvery white inside.

Remark. This species is similar to young individuals of Turbo (Batillus) cornutus (Lightfoot, 1786) (non spine type).

Distribution. Japan, Korea (Jeju-do).

\section{ACKNOWLEDGMENT}

This work was financially supported by a grant from the National Institute of Biological Resources (NIBR), funded by the Ministry of Environment (MOE) of the Republic of Korea. (NIBR No. 2013-02-001)

\section{REFERENCES}

Sowerby, G.B.III (1914) Descriptions of fifteen new Japanese marine mollusca. Annals and Magazine of Natural History, series 8, vol. 14: 33-39, pl. 2.

Beesley, P.L., Ross, G.J.B., and Wells, A. (eds) (1998) The Mollusca: The Southern Synthesis. Fauna of Australia. Vol. 5, Part A, xvi pp. 563. Part B, viii pp. 565-1234, CSIRO Publishing, Melbourne.

Higo, S., Callomon P. and Goto Y. (1999) Catalogue and bibliography of the marine shell bearing mollusca of Japan. Elle Scientific Publications. Osaka, Japan. pp. 1-749.

Kantor, Y. \& Sysoev, A.V. (2006) Marine and brackish water Gastopoda of Russia and adjacent contries: an illustrated catalogue. KMK Scientific Press Ltd. Moscow. [in Russian and English]

Lee, J.S. and D.K. Min. (2002) A catalogue of molluscan fauna in Korea. Korean Journal of Malacology, 18(2): 93-217.

Okutani, T. (ed.) (2000) Marine Mollusks in Japan. pp.1172, Tokai Univ. Press. Tokyo. [In Japanese and English]

Qi, Z. (ed.) (2004) Seashells of China. China Ocean Press, Beijing, China. 418 pp. 193 pls.

Min, D.K., Lee, J.S., Koh, D.B. and Je, J.K. (2004) Mollusks in Korea. Min Molluscan Research Institute. Seoul. 566 pp. [in Korean]

Habe, T. \& Okutani, T. (1975) Gakken Illustrated Nature Encyclopedia the Mollusks of Japan. Vol. I, Gakken Co., Tokyo. [In Japanese]

Higo, S. and Goto, Y. (1993) A systematic List of Mollusca Shells from the Japanese Is. and Adjacent Area. 693 pp. Yuko Publishing. Co., Ltd., Osaka. [in Japanese] 